\title{
Physiological and Biochemical Properties of Potato (Solanum tuberosum L.) in Response to Ozone-Induced Oxidative Stress
}

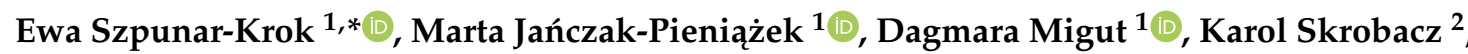 \\ Tomasz Piechowiak ${ }^{2}$, Renata Pawlak ${ }^{1}$ and Maciej Balawejder ${ }^{2}$ D \\ 1 Department of Crop Production, University of Rzeszow, Zelwerowicza 4, 35-601 Rzeszow, Poland; \\ mjanczak@ur.edu.pl (M.J.-P.); dmigut@ur.edu.pl (D.M.); pawlak_renata@o2.pl (R.P.) \\ 2 Department of Food Chemistry and Toxicology, University of Rzeszow, Ćwiklińskiej 1A, \\ 35-601 Rzeszów, Poland; karol.skrobacz@gmail.com (K.S.); tpiechowiak@ur.edu.pl (T.P.); \\ maciejb@ur.edu.pl (M.B.) \\ * Correspondence: szpunar-krok@wp.pl
}

Received: 30 September 2020; Accepted: 6 November 2020; Published: 10 November 2020

\begin{abstract}
We investigated the changes in the physiological and biochemical properties of potato plants exposed to differing ozone $\left(\mathrm{O}_{3}\right)$ concentrations $(5 \mathrm{ppm}, 10 \mathrm{ppm})$ and exposure times $(2,4,8,12$, $16 \mathrm{~min}$ ) to determine the safe dose that could be used in crop protection programs. We measured the gas exchange, relative chlorophyll content, chlorophyll fluorescence and total antioxidant capacity in potato leaves exposed to $\mathrm{O}_{3}$ fumigation. The fresh weight (FW) of the aboveground part of the plants and a visual assessment of plant condition were determined after the end of the experiment. The plants were given two $\mathrm{O}_{3}$ treatments and measurements were carried out four times: on the 1st and 7th day after treatment. We conclude that $\mathrm{O}_{3}$ exposure time had a greater impact on the reduction in the efficiency of the potato photosynthetic apparatus than $\mathrm{O}_{3}$ concentration. Research has showed that $\mathrm{O}_{3}$ in $5 \mathrm{ppm}$ concentration for 2 and $4 \mathrm{~min}$ and $10 \mathrm{ppm}$ for $2 \mathrm{~min}$ increased the efficiency of the photosynthesis and antioxidant activity in leaf processes, and these doses could be taken into account in further research on the potential for using $\mathrm{O}_{3}$ in potato protection.
\end{abstract}

Keywords: ozone; potato; gas exchange; chlorophyll content; chlorophyll fluorescence; antioxidant capacity

\section{Introduction}

Potatoes are the third most important crop in the world after wheat and rice, with an area of over 17.5 million hectares [1]. Potato tubers are a significant component of a diet and a valuable source of starch [2]. Chemical plant protection products are usually used to protect potato plants against diseases. In organic farming, where pesticides cannot be used, an alternative may be the use of ozone (trioxygen, $\mathrm{O}_{3}$ ), which has no negative impact on the environment and has disinfectant and antibacterial properties [3-6]. The primary purpose of ozonation is microbial decontamination due to its strong biocidal effect. Today, it is mainly used for the decontamination of raw materials and food products, as well as surface disinfection of equipment [7-11], and it increases the profitability of production by reducing losses during trading. There are also various reports in the literature on the possibility of using $\mathrm{O}_{3}$ as an elicitor to improve the quality of the raw material [12]. From a food safety point of view, it is important that $\mathrm{O}_{3}$ rapidly degrades to oxygen and leaves no residue so that it is safe and the ozonated product is suitable for food destined to be certified as organic food [6]. $\mathrm{O}_{3}$ treatment may have additional benefits, such as the effective degradation of pesticides $[13,14]$ and mycotoxins [15]. 
$\mathrm{O}_{3}$ is a reactive gaseous allotropic form of oxygen that plays a dual role in the atmosphere. Stratospheric $\mathrm{O}_{3}$ is a layer that protects life on Earth against harmful UV radiation, while tropospheric $\mathrm{O}_{3}$ is treated as a major air pollutant, reducing the productivity of crops, including potatoes [16-21]. Plant response to $\mathrm{O}_{3}$ is closely related to Reactive Oxygen Species (ROS) produced in the apoplast, which are important mediators of signal transduction pathways. [22]. In the process of diffusion, $\mathrm{O}_{3}$ enters the plants through the stomata and continues to penetrate the apoplast, where it is rapidly transformed into ROS, such as hydrogen peroxide $\left(\mathrm{H}_{2} \mathrm{O}_{2}\right)$, superoxide radicals $\left(\mathrm{O}_{2}{ }^{\bullet-}\right)$, and hydroxyl radicals $\left(\mathrm{OH}^{\bullet}\right)$, which can react with wall and cell membrane components [22,23]. $\mathrm{H}_{2} \mathrm{O}_{2}$ obtained, inter alia, as a result of $\mathrm{O}_{3}$ transformation, plays an important role in the regulation of physiological processes taking place in the plant cell. $\mathrm{H}_{2} \mathrm{O}_{2}$ is transported through the cell membrane, causes a change in gene expression and modulates transcription factors [24]. ROS can be detoxified by ROS scavengers inside the apoplast or they can react with proteins or plasma membrane lipids. In order to protect against toxic ROS, plant cells and organelles (mitochondria, chloroplasts, and peroxisomes) have developed an antioxidant defense system. However an imbalance between ROS and ROS scavenger production may result in oxidative stress $[25,26]$.

The effect of $\mathrm{O}_{3}$ on plants depends on its dose and exposure time [23,27]. Acute damage (high $\mathrm{O}_{3}$ dose within a short time frame) resembles the hypersensitive response (HR) in which the effect is similar to fungal elicitors, leading to programmed cell death (PCD) and leaf damage in sensitive species [28-30]. By contrast, chronic damage (low $\mathrm{O}_{3}$ dose within a long time frame) causes a decrease in the rate of photosynthesis, growth restriction and leaf senescence, leading to a decrease in plant productivity, without visible damage to the plant tissue [23,31,32]. A concentration of $\mathrm{O}_{3}$ in the air at a level of $40 \mathrm{ppb}$ is critical for plant crops, and above that level it can have a negative effect on their growth and yield [33]. The tolerance of plant genotypes to the action of $\mathrm{O}_{3}$ is also due to the different antioxidant activity of enzymes in the cell [34]. The degree of $\mathrm{O}_{3}$ cytotoxicity depends on its concentration, exposure time and the alternative oxidase (AOX) pool. Damage caused by $\mathrm{O}_{3}$ is visible in the form of necrotic spots. They can also be invisible, causing physiological damage and stomatal apparatus disorders which results in decrease in photosynthetic activity [29].

Although $\mathrm{O}_{3}$ is toxic to plants due to its strongly oxidizing properties leading to reduced photosynthesis, growth inhibition, and, consequently, reduced crop yields (Ueda et al., 2013), it could be used as an alternative and ecological biocidal agent. Properly selected doses and $\mathrm{O}_{3}$ exposure time can also be taken into account in plant protection [6,9].

The purpose of the study was to investigate the effect of $\mathrm{O}_{3}$ concentration ( $5 \mathrm{ppm}, 10 \mathrm{ppm}$ ) and exposure time $(2,4,8,12,16 \mathrm{~min})$ on the efficiency of the photosynthetic apparatus in potato plants (Solanum tuberosum L.) and to determine the safe dose that could be used in a potato crop protection program.

\section{Materials and Methods}

\subsection{Plant Materials and Experimental Layout}

The experiments were conducted at the University of Rzeszow (Poland). Potato plants (Solanum tuberosum L. cv. Santé) were cultivated according to the methodology proposed by Szpunar-Krok et al. [35].

$\mathrm{O}_{3}$ fumigation took place in a plastic chamber with a capacity of $180 \mathrm{~L}$ (dimensions $0.8 \times 0.4 \times 0.55 \mathrm{~m}$ ) made of a material (PP) resistant to ozone gas. A chamber was composed of two twin superimposed elements, which allowed the placement of undamaged plants inside. A set of four pots (corresponding to one replication) was placed in a chamber. The chamber was fed with $\mathrm{O}_{3}$ using an Ozone generator (CSI, Ekotech, Warszawa, Poland). The $\mathrm{O}_{3}$ concentration was measured with a UV-106-M ozone analyzer (2B-Technologies, Boulder, $\mathrm{CO}, \mathrm{USA}$ ). The $\mathrm{O}_{3}$ concentration was kept constantly in the range of $5 \mathrm{ppm}$ and $10 \mathrm{ppm} \pm 10 \%$. For each concentration, the fumigation process was carried out for 2, 4, 8, $12,16 \mathrm{~min}$. After the fumigation process, the plants were stored at room temperature. Two treatments 
were applied: the 1st fumigation 21 days after planting (plants had 8-9 leaves), the 2nd fumigation seven days after the first one.

\subsection{Physiological Measurements}

The physiological measurements occurring in the potato leaves were taken four times: on the 1st and 7th day after each $\mathrm{O}_{3}$ fumigation. The measurements were performed on the 1st or 2nd fully expanded leaves. The purpose of measuring physiological parameters on the 1st day after fumigation was to determine the level of plant stress caused by this treatment, and on the 7th day after fumigation, to check how plants cope with stress thanks to the activation of repair mechanisms. Measurements of physiological parameters and antioxidant activity in leaves were performed according to the methodology proposed by Szpunar-Krok et al. [35].

\subsubsection{Measuring Gas Exchange}

Leaf photosynthesis was measured with a photosynthesis measurement system (LC pro-SD, ADC Bioscientific Ltd., Herts, UK) on two fully expanded leaves per pot. The intensity of photosynthesis net $\left(\mathrm{P}_{\mathrm{N}}\right)$, transpiration rate $(\mathrm{E})$, stomatal conductance $\left(\mathrm{g}_{\mathrm{s}}\right)$, and intercellular $\mathrm{CO}_{2}$ concentration $\left(\mathrm{C}_{\mathrm{i}}\right)$ were measured. In the determination process, the light intensity was $1500 \mathrm{~mol} \mathrm{~m}^{-2} \mathrm{~s}^{-1}$. The LCpro-SD plant leaf photosynthesis chamber has a flow rate accuracy of $\pm 2 \%$ of its range.

\subsubsection{Measuring Relative Chlorophyll Content}

The relative chlorophyll (Chl) content was measured on five fully expanded potato leaves per pot using a hand-held Chlorophyll Content Meter CCM-200plus (Opti-Sciences, Hudson, NH, USA).

\subsubsection{Measuring Plant Chlorophyll Fluorescence}

Chlorophyll (Chl) fluorescence analysis was performed using a continuous excitation Pocket PEA fluorometer equipped with black leaf-clips (Pocket PEA, Hansatech Instruments, King's Lynn, Norfolk, UK). The fluorescence signal was collected in red actinic light with a peak wavelength of $627 \mathrm{~nm}$ light diode source and applied for $1 \mathrm{~s}$ at the maximal available intensity of $3500 \mu \mathrm{mol}($ photon) of photosynthetically active radiation (PAR) $\mathrm{m}^{-2} \mathrm{~s}^{-1}$. Fluorescence measurements were conducted on the adaxial leaf lamina away from the leaf vein after $30 \mathrm{~min}$ of dark adaptation, two measurements on each pot. The following parameters were measured: the maximal quantum yield of Photosystem II (PSII) photochemistry $\left(\mathrm{F}_{\mathrm{v}} / \mathrm{F}_{\mathrm{m}}\right)$, the maximum quantum yield of primary photochemistry $\left(\mathrm{F}_{\mathrm{v}} / \mathrm{F}_{0}\right)$, and the performance index (PI).

\subsection{Determination of Antioxidant Activity Using $A B T S^{\bullet+}$ and DPPH・ Radicals}

The antioxidant activities (AA) in potato leaves were determined according to Szpunar-Krok et al. [35]. Plant tissue (1 g) was milled and homogenized with $15 \mathrm{~mL}$ of $75 \%$ methanol solution. The homogenate was shaken for $30 \mathrm{~min}(150 \mathrm{rpm})$ and clarified by centrifugation at $7500 \cdot \mathrm{g}$ for $10 \mathrm{~min}$.

A calibration curve was prepared for $100 \mu \mathrm{M}-1.5 \mathrm{mM}$ solutions of $( \pm)$-6-hydroxy-2,5,7, 8-tetramethylchromane-2-carboxylic acid (Trolox) in methanol which was used to determine the antioxidant activity. The results obtained from the actual tests were presented as an equivalent of $\mu \mathrm{mol}$ of Trolox in $1 \mathrm{~g}$ of fresh leaf mass. For all samples of fumigated potatoes, three replications of the measurements of antioxidant activity were performed. The supernatant thus obtained was used to determine the $\mathrm{AA}\left(\mathrm{ABTS}^{\bullet+}\right.$ and $\left.\mathrm{DPPH}^{\bullet}\right)$. Measurements were performed in triplicate.

\subsubsection{Antioxidant Activity Against $\mathrm{ABTS}^{\bullet+}$}

First, a $7 \mathrm{mM}$ solution of 2,2-azino-bis(3-ethylbenzothiazoline-6-sulphonic acid) diammonium salt $\left(\right.$ ABTS $^{\bullet+}$ ) was prepared in a water solution of $2.45 \mathrm{mM} \mathrm{K}_{2} \mathrm{~S}_{2} \mathrm{O}_{8}$. Then, the solution was incubated 
in darkness for $24 \mathrm{~h}$. Before each analysis, solution of ABTS radicals was made by diluting the base solution with distilled water until an absorbance $0.7 \pm 0.02$ at $\lambda=734 \mathrm{~nm}$ was obtained. Next, a $1 \mathrm{~mL}$ solution of ABTS radicals was transferred to a glass tube, and $10 \mu \mathrm{l}$ of each sample was added. The solution prepared in this way was placed in darkness for six min. After the incubation process, the absorbance of the solutions was measured at $\lambda=734 \mathrm{~nm}$ (with a blank sample as reference).

\subsubsection{Antioxidant activity against $\mathrm{DPPH}^{\bullet}$}

$30 \mu \mathrm{L}$ of potato leaf extract was added to $1 \mathrm{~mL}$ of $100 \mu \mathrm{M}$ 2,2-di(4-tert-octylphenyl)-1-picrylhydrazyl, free radical $\left(\mathrm{DPPH}^{\bullet}\right)$ solution. The solution prepared in this way was incubated in darkness for $30 \mathrm{~min}$. Then, the absorbance was measured at $\lambda=515 \mathrm{~nm}$.

\subsection{Determination of Fresh Weight and Condition Assessment of Plants}

At the end of the experiment (7th day after the 2nd fumigation), the plant condition was visually assessed by assigning a 9-degree scale ( 9 corresponds to the absence of symptoms of damage to the leaves and stalks; 1 indicates total damage to the plants). The evaluation included the number of damaged leaves and stalks, degree of damage, and the turgor of the leaves and stalks. It was assumed that $9^{\circ}$ is equivalent to $0-5 \%, 8^{\circ}=6-15 \%, 7^{\circ}=16-25 \%, 6^{\circ}=26-40 \%, 5^{\circ}=41-60 \%, 4^{\circ}=61-75 \%$, $3^{\circ}=76-85,2^{\circ}=86-95 \%$, and $1^{\circ}=96-100 \%$ of the above-ground parts of plants with visible damage. The above-ground parts of plants were harvested and their fresh mass (FW) was weighed. The weight of plants from individual variants of the experiment was related to the weight of plants from the control (100\%), according to the Equation (1):

$$
F W_{(\%)}=\frac{m_{o z} \cdot 100}{m_{c}}
$$

where:

$F W_{(\%)}$-calculated fresh weight of plants;

$m_{0 z}$-mass of above-ground part of fumigated plants; and

$m_{c}-$ mass of above-ground part of control plants.

\subsection{Statistical Analysis}

Statistical analysis was performed using TIBCO Statistica 13.3.0 (TIBCO Software Inc., Palo Alto, CA, USA). In order to check the normality of the distribution at $\alpha=0.05$, the Shapiro-Wilk test was performed. The homogeneity of variance was also checked. Then, a two-way ANOVA test with repeated measurements was used (with time evaluation as a factor). The least significant difference was calculated with the Tukey test at $\alpha \leq 0.05$.

\section{Results}

\subsection{Influence of $\mathrm{O}_{3}$ Fumigation on the Efficiency Gas Exchange}

A significant influence of various $\mathrm{O}_{3}$ concentrations and exposure times on the parameters of gas exchange in the leaves of potato plants was observed at each measurement time (Figure 1, Table S1). On the 1st day after each fumigation (T1, T3), a significant decrease was found in net photosynthetic rate $\left(\mathrm{P}_{\mathrm{N}}\right)$, transpiration rate $(\mathrm{E})$, and stomatal conductance $\left(\mathrm{g}_{\mathrm{s}}\right)$ values as a result of longer exposure times, regardless of the $\mathrm{O}_{3}$ concentration. Data showed that shorter exposure times ( 2 and $4 \mathrm{~min}$ ) increased $\mathrm{P}_{\mathrm{N}}$ and $\mathrm{E}$ values compared to the control, but the differences were not significant. On the other hand, an increase in $\mathrm{g}_{\mathrm{s}}$ value was only observed for the concentration of $5 \mathrm{ppm}$ and time of $2 \mathrm{~min}$ (significant relationship in T3-the 1st day after the 2nd fumigation and no significant difference in $\mathrm{T} 1$ - the 1st day after the 1st fumigation compared to the control). In the case of $\mathrm{C}_{\mathrm{i}}$, in both these terms, an increase in exposure time resulted in an increase in the value of this parameter. A similar relationship 
for $\mathrm{E}$ was observed on $\mathrm{T} 3$ (the 1st day after the $2 \mathrm{nd} \mathrm{O}_{3}$ application). In the case of $\mathrm{P}_{\mathrm{N}}$ and $\mathrm{g}_{\mathrm{s}}$, only a lower concentration $(5 \mathrm{ppm})$ in shorter exposure times ( 2 and $4 \mathrm{~min}$ ) had a stimulating effect on the plants, but no significant effect of a higher $\mathrm{O}_{3}$ concentration on these parameters was demonstrated.
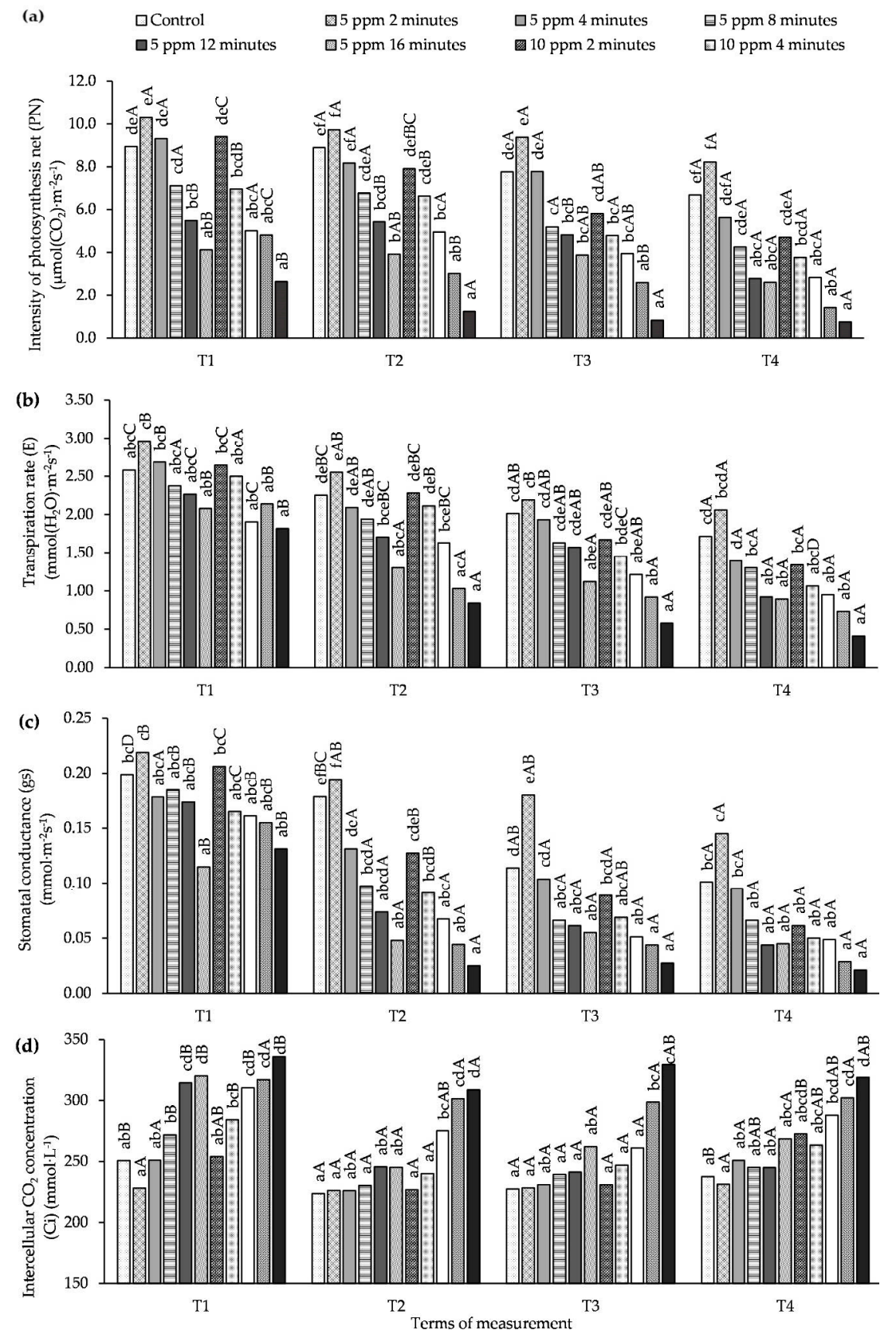

Figure 1. Changes in gas exchange parameters in potato leaves depending on $\mathrm{O}_{3}$ concentration, exposure time and measurement terms (T1-1st day after the 1st fumigation, T2 - 7th day after the 1st fumigation, T3-1st day after the 2nd fumigation, T4-7th day after the 2nd fumigation). (a) intensity of photosynthesis net $\left(\mathrm{P}_{\mathrm{N}}\right),(\mathbf{b})$ transpiration rate $(\mathrm{E})$, (c) stomatal conductance $\left(\mathrm{g}_{\mathrm{s}}\right)$, (d) intercellular $\mathrm{CO}_{2}$ concentration $\left(\mathrm{C}_{\mathrm{i}}\right)$. Lowercase letters indicate significant differences between the means at respective measurement terms, capital letters indicate significant differences between means at the measurement terms for the respective variants of $\mathrm{O}_{3}$ concentration and exposure time $(p<0.05)$.

On the 7th day after the 1st fumigation (T2) of potato plants with the lower $\mathrm{O}_{3}$ concentration for 2 and $4 \mathrm{~min}$, the $\mathrm{P}_{\mathrm{N}}$ values in the leaf did not differ significantly when compared to the control, 
but for 5 ppm concentration and 2 min time the values of this parameter were higher than in the plants not ozonated.

At this time point, no significant difference in the $\mathrm{P}_{\mathrm{N}}$ was found between the control and $10 \mathrm{ppm}$ concentration and $2 \mathrm{~min}$ time, while a further increase in $\mathrm{O}_{3}$ concentration and exposure time caused a decrease in $\mathrm{P}_{\mathrm{N}}$ values. At the $\mathrm{T} 2$ measurement term, a significant reduction in $\mathrm{E}$ value in relation to the control occurred under the influence of $5 \mathrm{ppm}$ treatment for $16 \mathrm{~min}$ and $10 \mathrm{ppm}$ for 12 and $16 \mathrm{~min}$. In all variants of the experiment, the $\mathrm{g}_{\mathrm{s}}$ values were then significantly decreased in relation to the control, except for $5 \mathrm{ppm}$ and $2 \mathrm{~min}$. On the T4 measurement term (the 7th day after the 2nd application), $\mathrm{P}_{\mathrm{N}}, \mathrm{E}$, and $\mathrm{g}_{\mathrm{s}}$ values only did not differ significantly compared to the control under the influence of fumigation with $5 \mathrm{ppm}$ for 2 and $4 \mathrm{~min}$. At all measurement dates, the increase in $\mathrm{O}_{3}$ concentration and exposure time caused an increase in $C_{i}$ values. Significantly, the highest $C_{i}$ values were obtained for a higher $\mathrm{O}_{3}$ concentration $(10 \mathrm{ppm})$ and an exposure time of $16 \mathrm{~min}$.

On the 1st day after each $\mathrm{O}_{3}$ fumigation (T1, T3), decreases in the values of the $\mathrm{P}_{\mathrm{N}}, \mathrm{E}$, and $\mathrm{g}_{\mathrm{s}}$ parameters were observed compared to the control, while, on the 7th day, after both applications $(T 2, T 4)$ there was an increase in their values. In the case of $C_{i}$, no such relationship was found.

\subsection{Influence of $\mathrm{O}_{3}$ Fumigation on Relative Chl Content}

The relative $\mathrm{Chl}$ content in potato leaves depended more on the concentration and exposure time of the plants to $\mathrm{O}_{3}$ than on the time of measurement (Figure 2, Table S2). On the 1st day, after each $\mathrm{O}_{3}$ fumigation of potato plants (T1, T3), a relative Chl content in the leaves that was higher than that in the control (but not significantly different) was obtained by treating the plants with an $\mathrm{O}_{3}$ concentration of $5 \mathrm{ppm}$ for 2 and $4 \mathrm{~min}$ and $10 \mathrm{ppm}$ for $2 \mathrm{~min}$. Under the influence of treating the plants with $10 \mathrm{ppm}$ for 4 and $8 \mathrm{~min}$, the relative Chl content at the T1 measurement term was lower than in the control, but did not differ significantly from it. Increasing the exposure time to 12 and $16 \mathrm{~min}$, regardless of the measurement date and $\mathrm{O}_{3}$ concentration, caused a significant decrease in the relative Chl content in leaves.

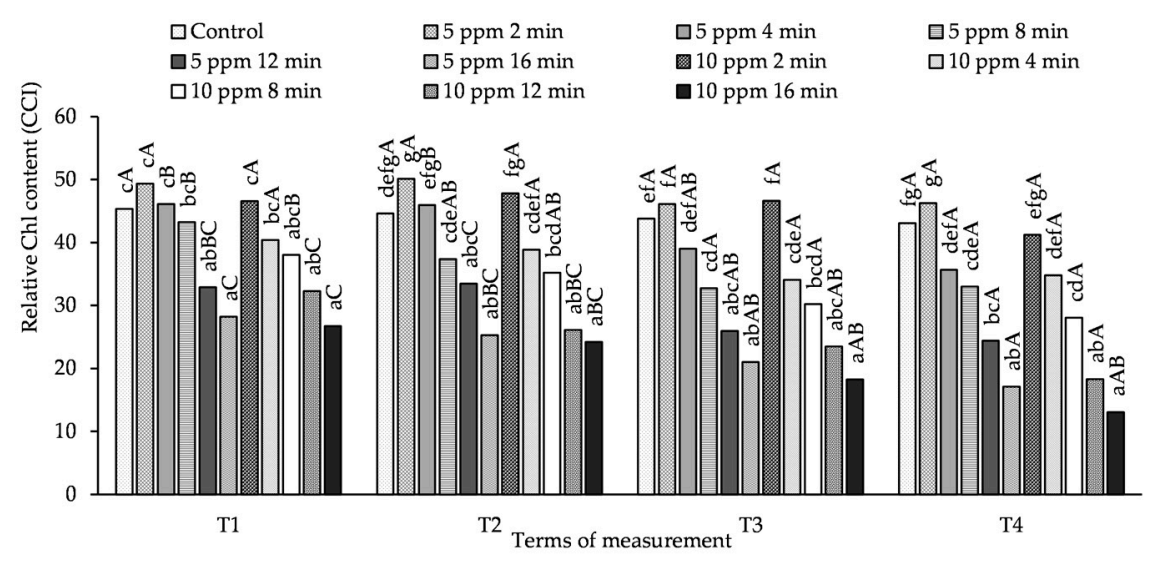

Figure 2. Changes in relative $\mathrm{Chl}$ content in potato leaves depending on $\mathrm{O}_{3}$ concentration, exposure time and measurement terms (T1-1st day after the 1st fumigation, T2-7th day after the 1st fumigation, T3-1st day after the 2nd fumigation, T4-7th day after the 2nd fumigation). Lowercase letters indicate significant differences between the means at respective measurement terms, capital letters indicate significant differences between means at the measurement terms for the respective variants of $\mathrm{O}_{3}$ concentration and exposure time $(p<0.05)$.

\subsection{Influence of $\mathrm{O}_{3}$ Fumigation on Chlorophyll Fluorescence}

At all measurement times (T1-T4), the value of the $\mathrm{F}_{\mathrm{v}} / \mathrm{F}_{\mathrm{m}}$ parameter obtained in the leaves of plants treated with an $\mathrm{O}_{3}$ concentration of $5 \mathrm{ppm}$ for $2 \mathrm{~min}$ was greater than or equal to the control (Figure 3, Table S3). A similar relationship was also observed for the concentration of $10 \mathrm{ppm}$ and time 
of $2 \mathrm{~min}$, but it was not a statistically significant difference. Under the influence of an $\mathrm{O}_{3}$ concentration of $5 \mathrm{ppm}$ for $16 \mathrm{~min}$ and a concentration of $10 \mathrm{ppm}$ and longer exposure times (12 and $16 \mathrm{~min}$ ), a significant decrease in the $F_{v} / F_{m}$ value in relation to the control was noted. Similar relationships were obtained for the parameters $\mathrm{F}_{\mathrm{v}} / \mathrm{F}_{0}$ and PI. At the T1 and T3 measurement terms (the 1st day after each ozonation of the plants) a decrease was observed in the values of the Chl fluorescence parameters $\left(\mathrm{F}_{\mathrm{v}} / \mathrm{F}_{\mathrm{m}}, \mathrm{F}_{\mathrm{v}} / \mathrm{F}_{0}\right.$ and $\left.\mathrm{PI}\right)$, while, at $\mathrm{T} 1$ and $\mathrm{T} 3$ (7th day after ozone treatment), the values of these parameters increased compared to the control.

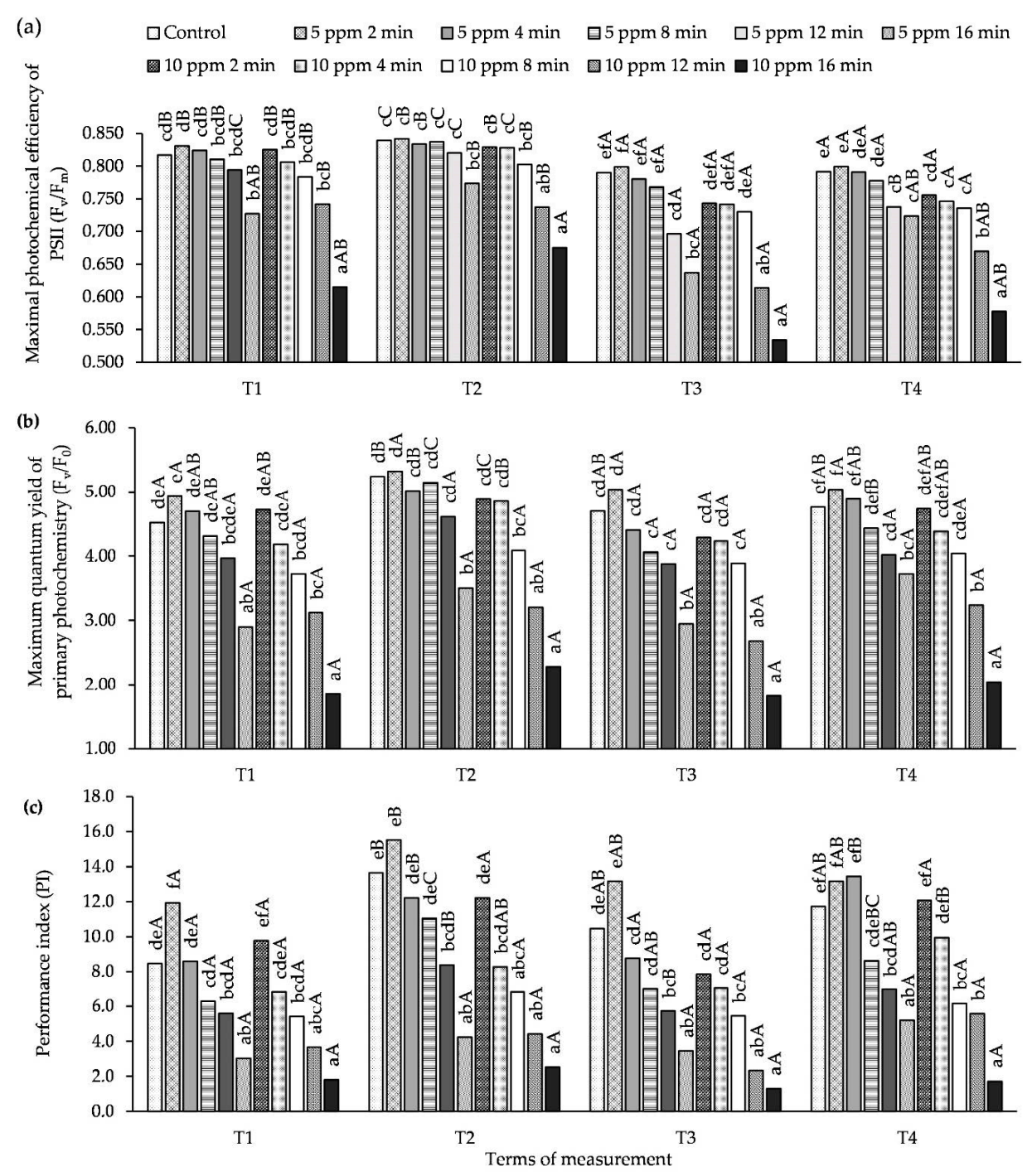

Figure 3. Changes in $\mathrm{Chl}$ fluorescence parameters in potato leaves depending on $\mathrm{O}_{3}$ concentration, exposure time and measurement terms (T1-1st day after the 1st fumigation, T2-7th day after the 1st fumigation, T3-1st day after the 2nd fumigation, T4-7th day after the 2nd fumigation): (a) $\mathrm{F}_{\mathrm{v}} / \mathrm{F}_{\mathrm{m}}$-maximal photochemical efficiency of Photosystem II (PSII), (b) $\mathrm{F}_{\mathrm{v}} / \mathrm{F}_{0}$-maximum quantum yield of primary photochemistry, (c) PI-performance index. Lowercase letters indicate significant differences between the means at respective measurement terms, capital letters indicate significant differences between means at the measurement terms for the respective variants of $\mathrm{O}_{3}$ concentration and exposure time $(p<0.05)$.

\subsection{Influence of $\mathrm{O}_{3}$ Fumigation on Antioxidant Activity}

The effect of plant concentration and exposure time to $\mathrm{O}_{3}$ on total antioxidant capacity (AA) in potato leaves is shown in Figure 4 and Table S4. In the experiment that was conducted, the use of a 
combination of $5 \mathrm{ppm}$ with shorter exposure times (from 2 to $8 \mathrm{~min}$ ) resulted in a significant increase in AA (both $\mathrm{ABTS}^{\bullet+}$ and $\mathrm{DPPH}^{\bullet}$ ) compared to the control at all measurement times. In the case of the concentration of $10 \mathrm{ppm}$, a similar relationship was only observed for the exposure times of 2 and $4 \mathrm{~min}$. At both concentrations, the lowest AA, was found in potato leaves treated with $\mathrm{O}_{3}$ at 5 ppm for 16 min, and, in the case of $10 \mathrm{ppm}$, also for $12 \mathrm{~min}$, both of which are significant results.

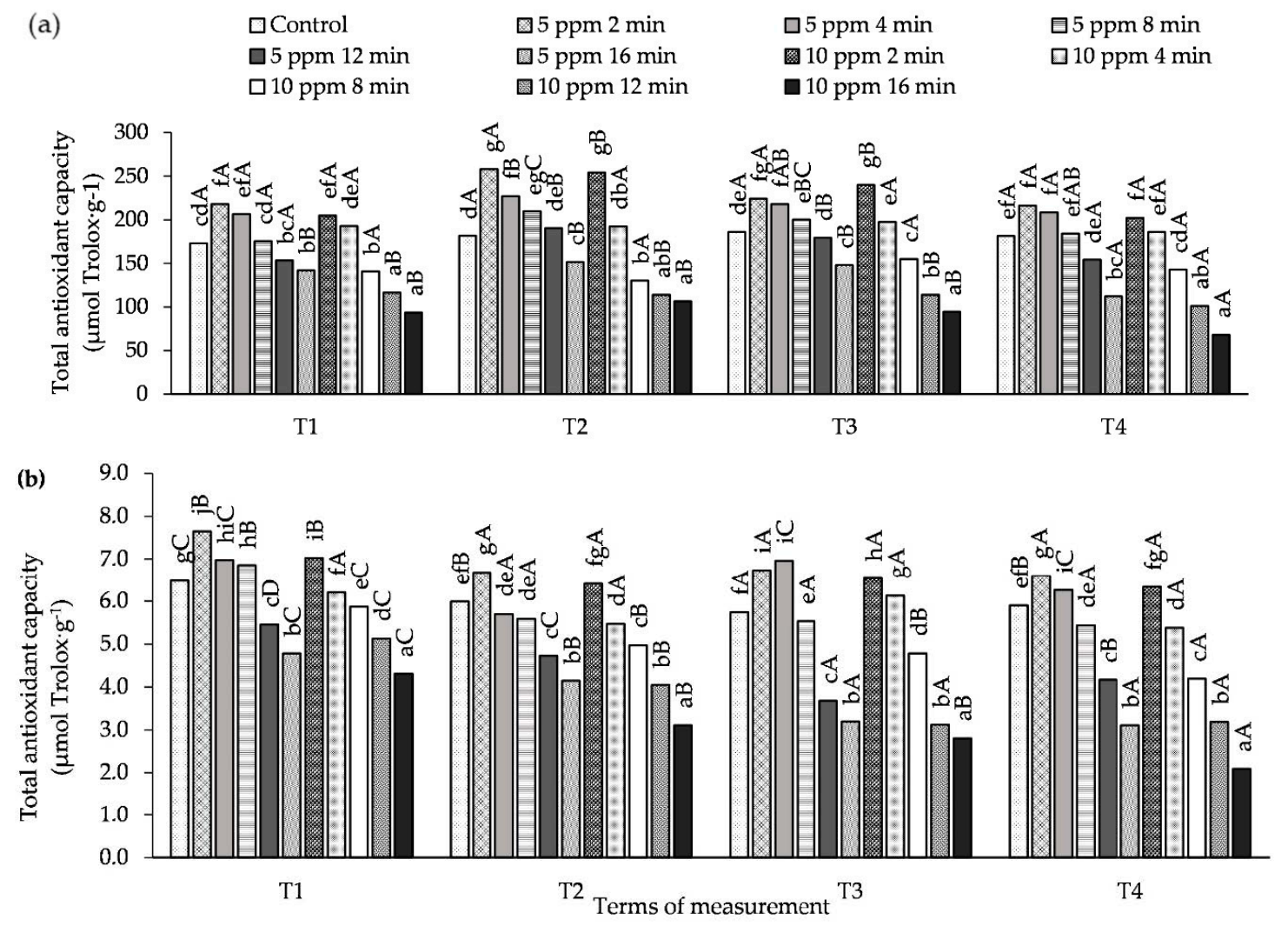

Figure 4. Changes in the total antioxidant capacity (AA) in potato leaves depending on $\mathrm{O}_{3}$ concentration, exposure time and measurement terms (T1-1st day after the 1st fumigation, T2-7th day after the 1st fumigation, T3-1st day after the 2nd fumigation, T4-7th day after the 2nd fumigation); (a) method with $\mathrm{ABTS}^{\bullet+}$ radical, (b) method with $\mathrm{DPPH}^{\bullet}$ radical. Lowercase letters indicate significant differences between the means at respective measurement terms, capital letters indicate significant differences between means at the measurement terms for the respective variants of $\mathrm{O}_{3}$ concentration and exposure time $(p<0.05)$.

\subsection{Influence of $\mathrm{O}_{3}$ Fumigation on the Fresh Weight and Condition of Plants}

A doubleO $\mathrm{O}_{3}$ fumigation of potato plants caused a reduction in the fresh weight (FW) of the aboveground parts of plants and a deterioration in their condition (Figure 5). The increase of the time of treating plants with $\mathrm{O}_{3}$ resulted in a gradual loss of FW of their aboveground parts and a deterioration in their condition. Only the use of an $\mathrm{O}_{3}$ concentration of $5 \mathrm{ppm}$ for $2 \mathrm{~min}$ did not reduce the weight of the plants and did not worsen their condition in relation to the control. A stronger reaction of the plants to fumigation was observed by treating them with a higher $\mathrm{O}_{3}$ concentration $(10 \mathrm{ppm})$. Double fumigation of plants with a concentration of $5 \mathrm{ppm}$ for $16 \mathrm{~min}$ resulted in a reduction in the FW of plants (by $40.4 \%$ ) compared to the control and the condition was rated at $3.5^{\circ}$, while, at a concentration of $10 \mathrm{ppm}$, there was a loss of FW (by $80.6 \%$ ) and a decrease in their condition to $2.0^{\circ}$. 


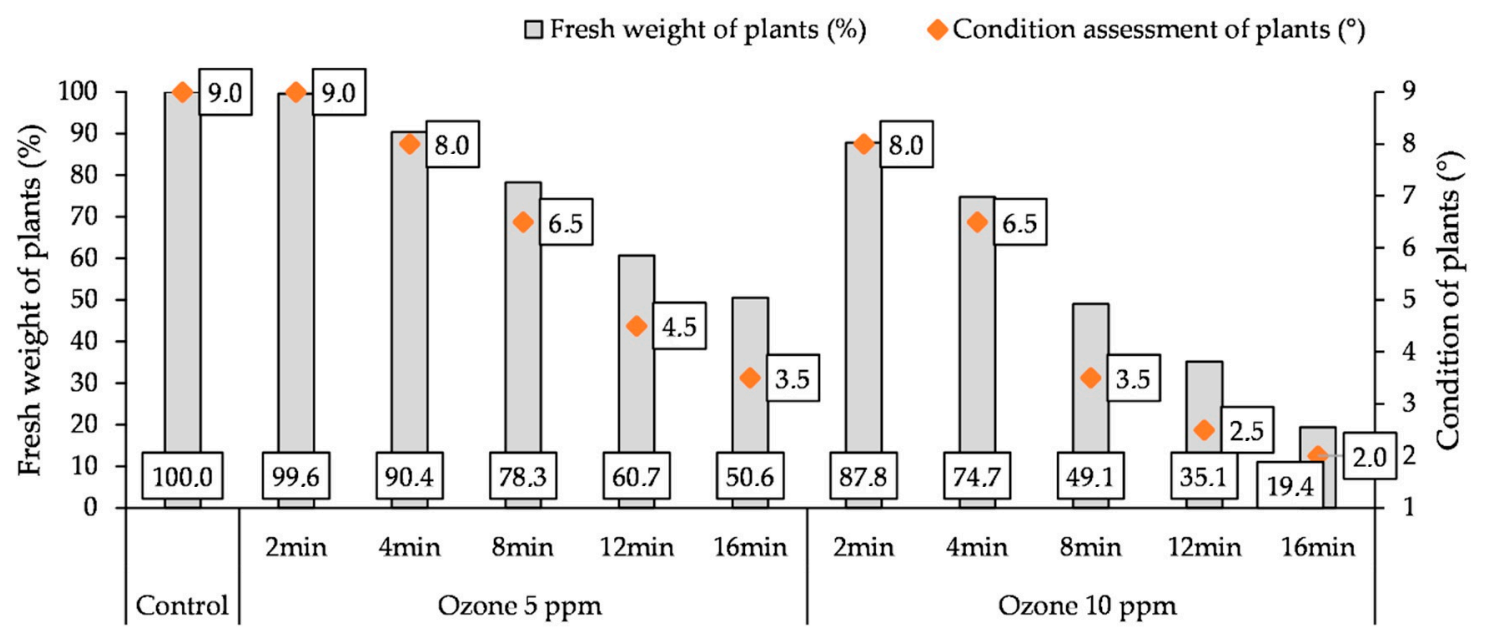

Figure 5. Changes in fresh weight (FW) of plants and condition assessment of plants (9-most favorable, 1 -least favorable) at the end of the experiment (7th day after the 2 nd $\mathrm{O}_{3}$ fumigation), depending on $\mathrm{O}_{3}$ concentration, exposure time, and measurement terms.

\section{Discussion}

In many European Union countries, treatments that protect potato plants against pathogens, including potato blight, the pathogen which causes the greatest losses, are carried out several times (every 7-10 days). Due to $\mathrm{O}_{3}$ having a short half-life and rapidly decomposing to oxygen [36-38], we suppose that the use of $\mathrm{O}_{3}$ for plant protection will also require repeated treatments. Previous reports considered $\mathrm{O}_{3}$ as an abiotic elicitor. $\mathrm{O}_{3}$ activates multiple signal pathways, which are strictly regulated at multiple levels [22].

Closing the stomata is the plant's first response to $\mathrm{O}_{3}$ [16]. This study reports a decrease in $\mathrm{g}_{\mathrm{s}}$ was found as a result of the action of $\mathrm{O}_{3}$, which in turn led to an accumulation of intracellular $\mathrm{CO}_{2}$ in the mesophyll and an increase in the value of $\mathrm{C}_{\mathrm{i}}$. This phenomenon was accompanied by a decrease in the intensity of photosynthesis net $\left(\mathrm{P}_{\mathrm{N}}\right)$. The high concentration of $\mathrm{O}_{3}$ in the mesophyll cell apoplast, even before stomatal closure, leads to excessive accumulation of ROS. When a certain level of ROS is reached, extracellular and intracellular signaling pathways are triggered, leading to hormonal, biochemical and transcriptional changes $[16,22] . \mathrm{O}_{3}$ enters the apoplast through the stomata, where it is degraded into ROS, causing an increase in the level of calcium in the cytosol, which in turn leads to the closure of the stomata regulated by the activity of ion channels (ion channel activity), thus limiting its further penetration [39].

Regardless of the $\mathrm{O}_{3}$ concentration, there was a significant decrease in $\mathrm{P}_{\mathrm{N}}, \mathrm{E}$ and $\mathrm{g}_{\mathrm{s}}$ values on the day following each fumigation due to longer exposure times, however, shorter exposure times ( 2 and $4 \mathrm{~min}$ ) even caused a slight increase in the net photosynthetic rate $\left(\mathrm{P}_{\mathrm{N}}\right)$ and transpiration rate $(\mathrm{E})$ compared to the control. The $\mathrm{g}_{\mathrm{s}}$ increase was only observed for the shortest treatment time $(2 \mathrm{~min})$ and lower $\mathrm{O}_{3}$ concentration (5 ppm). In addition, a study conducted by $\mathrm{Xu}$ et al. [40] reported an increase in photosynthetic limitation with duration of exposure to $\mathrm{O}_{3}$. Singh et al. [41] indicated that elevated $\mathrm{O}_{3}$ led to reductions in the rate of photosynthesis (8.0-32.8\%) and stomatal conductance (10.3-31.5\%) in wheat. Dan and Pell [42] reported that one of the reasons for the reduced photosynthetic capacity of plants treated with $\mathrm{O}_{3}$ is a decrease in the content of ribulose-1,5-bisphosphate carboxylase/oxygenase (Rubisco), an important protein involved in foliar storage. The decreases in Rubisco content in potato leaves is one of the reasons for lowered photosynthetic capacity of $\mathrm{O}_{3}$-treated plants and could contribute to premature senescence associated with toxicity of this molecule [42] and it lowers the $\mathrm{CO}_{2}$ binding process in the Calvin-Benson cycle [43]. In the research presented, the increase in time of exposure to $\mathrm{O}_{3}$ resulted in an increase in intercellular $\mathrm{CO}_{2}$ concentrations $\left(\mathrm{C}_{\mathrm{i}}\right)$, which indicates a decrease in the $\mathrm{CO}_{2}$ connection capacity of the Calvin-Benson cycle. On the 7th day after each 
application, it was found that $\mathrm{P}_{\mathrm{N}}$ was restored to control level, but this was only shown for a concentration of $5 \mathrm{ppm}$ and an exposure time of 2 and $4 \mathrm{~min}$ after both fumigations and $10 \mathrm{ppm}$ and 2 min after the 1st fumigation. The restoration of $\mathrm{P}_{\mathrm{N}}$ at the end of $\mathrm{O}_{3}$ exposure is consistent with the observations of other researchers. In addition, Dan and Pell [42], treating potato plants with lower $\mathrm{O}_{3}$ concentrations ( 0.06 to $0.08 \mathrm{ppm}$ ) but for a longer time (from 1000 to $1600 \mathrm{~h}$ for 4 days) than in our research, observed an initial decrease in $P_{N}$ values which recovered to near control levels 3 days after the exposure ended. The recovery was related to stomatal reopening after the stress was removed, which was observed in these studies, but only for the shortest exposure time $(2 \mathrm{~min})$ and 5 ppm concentration. Increasing the exposure time, regardless of the $\mathrm{O}_{3}$ concentration, resulted in a significant reduction in photosynthetic efficiency compared to the control, which indicates degradation of the photosynthetic apparatus. This is confirmed by other studies [44].

Regardless of the $\mathrm{O}_{3}$ concentration, the short time $(2 \mathrm{~min})$ of exposure of the potato plants to $\mathrm{O}_{3}$ also increased the relative $\mathrm{Chl}$ content in the leaves in relation to the control at all times when measurement was carried out, which may indicate its stimulating effect as an elicitor. Increasing the exposure time, especially at a higher $\mathrm{O}_{3}$ concentration, caused a decrease in relative Chl content in the leaves, which may be related to oxidation processes in cells under the influence of $\mathrm{O}_{3}$ and increased permeability of the cell membrane [21,45], destruction of the thylakoids in chloroplasts, and ion leakage, which in turn leads to changes in Chl fluorescence.

The measurement of Chl fluorescence is a non-destructive and highly sensitive method of assessing the physiological condition of plants and is used in plants exposed to stress, including exposure to $\mathrm{O}_{3}$, showing its toxic effects on plants at an early stage, before the appearance of visible changes [46]. Chl fluorescence is a good indicator of PSII photoinhibition, showing changes in photosynthetic efficiency under the influence of $\mathrm{O}_{3}$ [39]. Shorter $\mathrm{O}_{3}$ fumigation times $(2,4$, and $8 \mathrm{~min})$, regardless of concentration, had no significant effect on the formation of $\mathrm{F}_{\mathrm{v}} / \mathrm{F}_{\mathrm{m}}$. On the other hand, the extension of the ozonation time of potato plants resulted in a significant decrease in the $\mathrm{F}_{\mathrm{v}} / \mathrm{F}_{\mathrm{m}}$ value due to the deterioration in the efficiency of energy conversion in PSII and the reduction of the quinone pool, which is confirmed in the literature [45,47]. Similar relationships were observed for the $F_{v} / F_{m}$, $\mathrm{F}_{\mathrm{v}} / \mathrm{F}_{0}$ and PI parameters. In the experiment, the $\mathrm{P}_{\mathrm{N}}$ parameter was a more sensitive indicator and indicated the effect of the stress of potato plants on the action of $\mathrm{O}_{3}$ more quickly than the chlorophyll fluorescence parameter. It was shown that for longer exposure times ( 8 and $12 \mathrm{~min}$ in the 1st and 7th day after the 1st fumigation and $8 \mathrm{~min}$ in the 1st and 7th day after the 2nd fumigation), regardless of the concentration of $\mathrm{O}_{3}$, the values of the $\mathrm{F}_{\mathrm{v}} / \mathrm{F}_{\mathrm{m}}$ parameter did not differ significantly when compared to the control, while the $\mathrm{P}_{\mathrm{N}}$ values did not differ. This only occurred after treatment with a concentration of $5 \mathrm{ppm}$ for 2 and $4 \mathrm{~min}$ (at all measurement times) and $10 \mathrm{ppm}$ for $2 \mathrm{~min}$ (the 1st day and 7th day after 1st fumigation). In addition, Płażek et al. [45], looking at the action of $\mathrm{O}_{3}$ on plants of other species, found a reduction in $\mathrm{P}_{\mathrm{N}}$ and did not show a decrease in $\mathrm{F}_{\mathrm{v}} / \mathrm{F}_{\mathrm{m}}$, while Ismail et al. [39] showed a decrease in both parameters. The fast recovery of the $\mathrm{F}_{\mathrm{v}} / \mathrm{F}_{\mathrm{m}}$ ratio $24 \mathrm{~h}$ after the end of fumigation indicates that chronic photoinhibition did not take place, as Guidi et al. [46] also reported.

Antioxidant activity (AA) is another indicator that can be used to assess the impact of stress on plants.

The use of $\mathrm{O}_{3}$ at a concentration of $5 \mathrm{ppm}$ and shorter exposure times ( 2 to $8 \mathrm{~min}$ ) resulted in an increase in antioxidant activity at all measurement times when compared to the control. In the case of a concentration of $10 \mathrm{ppm}$, a similar relationship was only observed for the exposure times of 2 and $4 \mathrm{~min}$. In these studies, however, a further increase in exposure time resulted in a significant decrease in AA, which indicates an imbalance between ROS and ROS scavengers, an effect that increases oxidative stress and may eventually trigger senescence at $\mathrm{O}_{3}$ concentrations of $5 \mathrm{ppm}$ for $16 \mathrm{~min}$, and in the case of $10 \mathrm{ppm}$, also for $12 \mathrm{~min}$. Antioxidant enzymes are found in plants, which cause a cascade of biochemical reactions, leading to the production of compounds that protect them from the toxic effects of oxidants [48]. Piechowiak and Balawejder [8] have shown that the $\mathrm{O}_{3}$ process increases the activity of PAL (phenylalanine ammonia-lyase), which plays an important role in the biosynthesis of 
phenolic compounds in plants. These compounds can act directly in detoxification of ROS in plant cells [49]. In addition, Sarkar at al. [50] reported an increase in the levels of major antioxidant enzymes: ascorbate peroxidase (APX) and glutathione reductase (GR) in two varieties of rice after exposure to elevated levels of $\mathrm{O}_{3}$. Similar relationships concerning APX induction under the influence of $\mathrm{O}_{3}$ induced stress were also noted in different wheat cultivars [51,52], rice [53,54] and maize [55]. In these studies, fumigation of potato plants with higher $\mathrm{O}_{3}$ concentrations than those used by these authors did not adversely affect the potato plants, but this is only true for shorter exposure times. Concentrations of $\mathrm{O}_{3}(5 \mathrm{ppm}$ and $10 \mathrm{ppm})$ which were considered high for plants were used in the experiment. Their use for 2 and 4 min did not cause a decrease in the efficiency of the photosynthetic apparatus, while, when used for a long time, they caused its degradation, which in turn led to a reduction in plant FW and a deterioration of their condition. Płażek et al. [45] showed that the plants were damaged by $\mathrm{O}_{3}$. This manifested itself in senescence and yellowing of the leaves, which was also observed in their own experiment. The induction of accelerated leaf senescence under the influence of $\mathrm{O}_{3}$ has already been described in previous studies [20,23,31,32]. Research by Ong et al. [56] showed that $\mathrm{O}_{3}$ at a concentration of $4 \mathrm{ppm}$, which was treated with papaya fruit after harvesting, damaged the structure of Colletotrichum gloeosporioides (disintegration of spore structure), causing its disintegration on the surface of the fruit. In addition, Ueda et al. [24] observed damage to rice leaves after $\mathrm{O}_{3}$ fumigation at a concentration of $150 \mathrm{ppb}$ for six h. This situation could have been caused by lipid peroxidation due to formation of the hydroxyl radical $\left(\mathrm{OH}^{\bullet}\right)$, which is the most reactive of oxygen species, formed by the Haber-Weiss/Fenton reaction [24,26], and which leads to cell death. $\mathrm{O}_{3}$ stress caused reduction in potato FW due to the non-availability of enough assimilates. According to Rai et al. [57], plants allocate more carbon towards the production of antioxidants and secondary metabolites for repair processes to overcome the stress induced by $\mathrm{O}_{3}$.

\section{Conclusions}

This study investigated the changes in the physiological and biochemical properties of potato plants exposed to gradients $\mathrm{O}_{3}$ concentration over time. Among the variants tested, $\mathrm{O}_{3}$ fumigation at a concentration of $5 \mathrm{ppm}$ for 2 and $4 \mathrm{~min}$ and $10 \mathrm{ppm}$ for $2 \mathrm{~min}$ had the most stimulating effect on the course of physiological processes in the leaves and did not cause a deterioration in the condition of the plants compared to the control. As a result of using these combinations, the highest values of gas exchange parameters $\left(\mathrm{P}_{\mathrm{N}}, \mathrm{g}_{\mathrm{s}}\right.$, and $\left.\mathrm{E}\right)$, relative chlorophyll content, and chlorophyll fluorescence $\left(\mathrm{F}_{\mathrm{v}} / \mathrm{F}_{\mathrm{m}}, \mathrm{F}_{\mathrm{v}} / \mathrm{F}_{0}\right.$, and PI) were obtained, and the highest antioxidant activity $\left(\mathrm{ABTS}^{\bullet+}\right.$ and $\left.\mathrm{DPPH}{ }^{\bullet}\right)$ was found. The use of $\mathrm{O}_{3}$ in these concentrations and exposure times could be considered targets for further research into the possibility using $\mathrm{O}_{3}$ as an alternative method of protection of potato plant with a product especially dedicated to sustainable and organic farming.

Supplementary Materials: The following are available online at http://www.mdpi.com/2073-4395/10/11/1745/s1, Table S1: Gas exchange, Table S2: Relative Chl content, Table S3: Chl fluorescence, Table S4: Antioxidant activity.

Author Contributions: E.S.-K. and M.B. have contributed in developing the research ideas, analyzing the data, conducting the research and writing the manuscript; M.J.-P. and D.M. have contributed in analyzing the data and writing the manuscript; K.S., T.P., R.P. have contributed in investigation. All authors have read and agreed to the published version of the manuscript.

Funding: This research was funded by the program of the Minister of Science and Higher Education named "Regional Initiative of Excellence" in the years 2019-2022, project number 026/RID/2018/19, the amount of financing PLN 9,542,500.00.

Conflicts of Interest: The authors declare no conflict of interest. 


\section{References}

1. FAOSTAT. Available online: http://www.fao.org/faostat/en/\#data/QC (accessed on 24 September 2020).

2. Birch, P.R.J.; Bryan, G.J.; Fenton, B.; Gilroy, E.M.; Hein, I.; Jones, J.T.; Prashar, A.; Taylor, M.A.; Torrance, L.; Toth, I.K. Crops that feed the world 8: Potato: Are the trends of increased global production sustainable? Food Secur. 2012, 4, 477-508. [CrossRef]

3. Remondino, M.; Valdenassi, L. Different Uses of Ozone: Environmental and Corporate Sustainability. Literature Review and Case Study. Sustainability 2018, 10, 4783. [CrossRef]

4. Carletti, L.; Botondi, R.; Moscetti, R.; Stella, E.; Monacra, D.; Cecchini, M.; Massantini, R. Use of ozone in sanitation and storage of fresh fruits and vegetables. J. Food Agric. Environ. 2013, 11, 585-589.

5. Zhang, X.; Zhang, Z.; Wang, L.; Zhang, Z.; Li, J.; Zhao, C. Impact of ozone on quality of strawberry during cold storage. Front. Agric. China 2011, 5, 356-360. [CrossRef]

6. Selma, M.V.; Ibáñez, A.M.; Cantwell, M.; Suslow, T. Reduction by gaseous ozone of Salmonella and microbial flora associated with fresh-cut cantaloupe. Food Microbiol. 2008, 25, 558-565. [CrossRef] [PubMed]

7. Piechowiak, T.; Antos, P.; Kosowski, P.; Skrobacz, K.; Józefczyk, R.; Balawejder, M. Impact of ozonation process on the microbiological and antioxidant status of raspberry (Rubus ideaeus L.) fruit during storage at room temperature. Agric. Food Sci. 2019, 28, 35-44. [CrossRef]

8. Piechowiak, T.; Balawejder, M. Impact of ozonation process on the level of selected oxidative stress markers in raspberries stored at room temperature. Food Chem. 2019, 298, 125093. [CrossRef]

9. Pandiselvam, R.; Subhashini, S.; Priya, E.B.; Kothakota, A.; Ramesh, S.; Shahir, S. Ozone based food preservation: A promising green technology for enhanced food safety. Ozone Sci. Eng. 2018, 41, 17-34. [CrossRef]

10. Kim, J.-G.; Yousef, A.E.; Khadre, M.A. Ozone and its current and future application in the food industry. Adv. Food Nutr. Res. 2003, 45, 167-218. [CrossRef]

11. Kells, S.A.; Mason, L.J.; Maier, D.E.; Woloshuk, C.P. Efficacy and fumigation characteristics of ozone in stored maize. J. Stored Prod. Res. 2001, 37, 371-382. [CrossRef]

12. Sachadyn-Król, M.; Agriopoulou, S. Ozonation as a Method of Abiotic Elicitation Improving the Health-Promoting Properties of Plant Products-A Review. Molecules 2020, 25, 2416. [CrossRef] [PubMed]

13. Conte, G.; Fontanelli, M.; Galli, F.; Cotrozzi, L.; Pagni, L.; Pellegrini, E. Mycotoxins in Feed and Food and the Role of Ozone in Their Detoxification and Degradation: An Update. Toxins 2020, 12, 486. [CrossRef] [PubMed]

14. Sadło, S.; Szpyrka, E.; Piechowicz, B.; Antos, P.; Józefczyk, R.; Balawejder, M. Reduction of Captan, Boscalid and Pyraclostrobin Residues on Apples Using Water Only, Gaseous Ozone and Ozone Aqueous Solution. Ozone: Sci. Eng. 2016, 39, 97-103. [CrossRef]

15. Zhu, F. Effect of ozone treatment on the quality of grain products. Food Chem. 2018, 264, 358-366. [CrossRef] [PubMed]

16. Ainsworth, E.A. Understanding and improving global crop response to ozone pollution. Plant J. 2016, 90, 886-897. [CrossRef]

17. Mina, U.; Kumar, P.; Varshney, C.K. Effect of ozone stress on different growth stages of potato (Solanum tuberosum). Phyton 2010, 49, 253-266. Available online: https://www.verlag-berger.at/detailview? no $=2746$ (accessed on 24 September 2020).

18. Rai, R.; Agrawal, M. Impact of Tropospheric Ozone on Crop Plants. Proc. Natl. Acad. Sci. India Sect. B Boil. Sci. 2012, 82, 241-257. [CrossRef]

19. Asensi-Fabado, A.; García-Breijo, F.; Reig-Armiñana, J. Ozone-induced reductions in below-ground biomass: An anatomical approach in potato. Plant Cell Environ. 2010, 33, 1070-1083. [CrossRef]

20. Fuhrer, J.; Booker, F. Ecological issues related to ozone: Agricultural issues. Environ. Int. 2003, 29, 141-154. [CrossRef]

21. Chernikova, T.; Robinson, J.M.; Lee, E.H.; Mulchi, C.L. Ozone tolerance and antioxidant enzyme activity in soybean cultivars. Photosynth. Res. 2000, 64, 15-26. [CrossRef]

22. Vainonen, J.P.; Kangasjärvi, J. Plant signalling in acute ozone exposure. Plant Cell Environ. 2014, 38, $240-252$. [CrossRef] [PubMed]

23. Castagna, A.; Ranieri, A. Detoxification and repair process of ozone injury: From $\mathrm{O}_{3}$ uptake to gene expression adjustment. Environ. Pollut. 2009, 157, 1461-1469. [CrossRef] [PubMed] 
24. Ueda, Y.; Uehara, N.; Sasaki, H.; Kobayashi, K.; Yamakawa, T. Impacts of acute ozone stress on superoxide dismutase (SOD) expression and reactive oxygen species (ROS) formation in rice leaves. Plant Physiol. Biochem. 2013, 70, 396-402. [CrossRef] [PubMed]

25. Das, K.; Roychoudhury, A. Reactive oxygen species (ROS) and response of antioxidants as ROS-scavengers during environmental stress in plants. Front. Environ. Sci. 2014, 2, 1-13. [CrossRef]

26. Gill, S.S.; Tuteja, N. Reactive oxygen species and antioxidant machinery in abiotic stress tolerance in crop plants. Plant Physiol. Biochem. 2010, 48, 909-930. [CrossRef]

27. Chen, C.P.; Frank, T.D.; Long, S.P. Is a short, sharp shock equivalent to long-term punishment? Contrasting the spatial pattern of acute and chronic ozone damage to soybean leaves via chlorophyll fluorescence imaging. Plant Cell Environ. 2009, 32, 327-335. [CrossRef]

28. Bandurska, H.; Borowiak, K.; Zielezińska, M. Oxidative stress enzymes in tobacco during a long-term exposure to ambient ozone at two different sites. Arch. Environ. Prot. 2018, 44, 3-11. [CrossRef]

29. Iriti, M.; Faoro, F. Oxidative Stress, the Paradigm of Ozone Toxicity in Plants and Animals. Water Air Soil Pollut. 2007, 187, 285-301. [CrossRef]

30. Rao, M.V.; Koch, J.R.; Davis, K. Ozone: A tool for probing programmed cell death in plants. Plant Mol. Biol. 2000, 44, 345-358. [CrossRef]

31. Krupa, S.V. Joint Effects of Elevated Levels of Ultraviolet-B Radiation, Carbon Dioxide and Ozone on Plants. Photochem. Photobiol. 2003, 78, 535-542. [CrossRef]

32. Sandermann, H.; Ernst, D.; Heller, W.; Langebartels, C. Ozone: An abiotic elicitor of plant defence reactions. Trends Plant Sci. 1998, 3, 47-50. [CrossRef]

33. Directive 2008/50/EC of the European Parliament and of the Council of 21 May 2008 on Ambient Air Quality and Cleaner Air for Europe. Available online: https:/eur-lex.europa.eu/legal-content/en/ALL/?uri=CELEX\% 3A32008L0050 (accessed on 24 September 2020).

34. Guri, A. Variation in glutathione and ascorbic acid content among selected cultivars of Phaseolus vulgaris prior to and after exposure to ozone. Can J. Plant Sci. 1983, 63, 733-737. [CrossRef]

35. Szpunar-Krok, E.; Jańczak-Pieniazżek, M.; Skrobacz, K.; Bobrecka-Jamro, D.; Balawejder, M. Response of Potato (Solanum Tuberosum L.) Plants to Spraying by Hydrogen Peroxide. Sustainability 2020, 12, 2469. [CrossRef]

36. Afsah-Hejri, L.; Hajeb, P.; Ehsani, R.J. Application of ozone for degradation of mycotoxins in food: A review. Compr. Rev. Food Sci. Food Saf. 2020, 19, 1777-1808. [CrossRef]

37. Glowacz, M.; Rees, D. The practicality of using ozone with fruit and vegetables. J. Sci. Food Agric. 2016, 96, 4637-4643. [CrossRef]

38. Gabler, F.M.; Smilanick, J.L.; Mansour, M.F.; Karaca, H. Influence of fumigation with high concentrations of ozone gas on postharvest gray mold and fungicide residues on table grapes. Postharvest Biol. Technol. 2010, 55, 85-90. [CrossRef]

39. Ismail, I.; Basahi, J.; Hassan, I.A. Gas exchange and chlorophyll fluorescence of pea (Pisum sativum L.) plants in response to ambient ozone at a rural site in Egypt. Sci. Total. Environ. 2014, 497, 585-593. [CrossRef]

40. Xu, Y.; Feng, Z.; Shang, B.; Dai, L.; Uddling, J.; Tarvainen, L. Mesophyll conductance limitation of photosynthesis in poplar under elevated ozone. Sci. Total. Environ. 2019, 657, 136-145. [CrossRef]

41. Singh, A.A.; Fatima, A.; Mishra, A.K.; Chaudhary, N.; Mukherjee, A.; Agrawal, M.; Agrawal, S.B. Assessment of ozone toxicity among 14 Indian wheat cultivars under field conditions: Growth and productivity. Environ. Monit. Assess. 2018, 190, 190. [CrossRef]

42. Dann, M.S.; Pell, E.J. Decline of Activity and Quantity of Ribulose Bisphosphate Carboxylase/Oxygenase and Net Photosynthesis in Ozone-Treated Potato Foliage. Plant Physiol. 1989, 91, 427-432. [CrossRef]

43. Degl'Innocenti, E.; Guidi, L.; Soldatini, G. Effect of Chronic $\mathrm{O}_{3}$ Fumigation on the Activity of Some Calvin Cycle Enzymes in Two Poplar Clones. Photosynthetica 2002, 40, 121-126. [CrossRef]

44. Thwe, A.A.; Vercambre, G.; Gautier, H.; Gay, F.; Phattaralerphong, J.; Kasemsap, P. Response of photosynthesis and chlorophyll fluorescence to acute ozone stress in tomato (Solanum lycopersicum Mill.). Photosynthetica 2014, 52, 105-116. [CrossRef]

45. Płażek, A.; Rapacz, M.; Skoczowski, A. Effects of Ozone Fumigation on Photosynthesis and Membrane Permeability in Leaves of Spring Barley, Meadow Fescue, and Winter Rape. Photosynthetica 2000, 38, 409-413. [CrossRef] 
46. Guidi, L.; Mori, S.; Degl'Innocenti, E.; Pecchia, S. Effects of ozone exposure or fungal pathogen on white lupin leaves as determined by imaging of chlorophyll a fluorescence. Plant Physiol. Biochem. 2007, 45, 851-857. [CrossRef]

47. Feng, Z.-Z.; Yao, F.-F.; Chen, Z.; Wang, X.; Zheng, Q.-W.; Feng, Z.-W. Response of gas exchange and yield components of field-grown Triticum aestivum L. to elevated ozone in China. Photosynthetica 2007, 45, 441-446. [CrossRef]

48. Zhou, Q.; Ma, C.; Cheng, S.; Wei, B.; Liu, X.; Ji, S. Changes in antioxidative metabolism accompanying pitting development in stored blueberry fruit. Postharvest Biol. Technol. 2014, 88, 88-95. [CrossRef]

49. Choudhury, F.K.; Rivero, R.M.; Blumwald, E.; Mittler, R. Reactive oxygen species, abiotic stress and stress combination. Plant J. 2016, 90, 856-867. [CrossRef]

50. Sarkar, A.; Singh, A.A.; Agrawal, S.B.; Ahmad, A.; Rai, S.P. Cultivar specific variations in antioxidative defense system, genome and proteome of two tropical rice cultivars against ambient and elevated ozone. Ecotoxicol. Environ. Saf. 2015, 115, 101-111. [CrossRef]

51. Sarkar, A.; Rakwal, R.; Agrawal, S.B.; Shibato, J.; Ogawa, Y.; Yoshida, Y.; Agrawal, G.K.; Agrawal, S.B. Investigating the Impact of Elevated Levels of Ozone on Tropical Wheat Using Integrated Phenotypical, Physiological, Biochemical, and Proteomics Approaches. J. Proteome Res. 2010, 9, 4565-4584. [CrossRef]

52. Agrawal, G.K.; Rakwal, R.; Yonekura, M.; Saji, H. Rapid induction of defense/stress related proteins in leaves of rice (Oryza sativa) seedlings exposed to ozone is preceeded by newly phosphorylated proteins and changes in 66 K-Da ERK-type MAPK. J. Plant Physiol. 2002, 159, 361-369. [CrossRef]

53. Rai, R.; Agrawal, S.B. Assessment of competitive ability of two Indian wheat cultivars under ambient $\mathrm{O}_{3}$ at different developmental stages. Environ. Sci. Pollut. Res. 2013, 21, 1039-1053. [CrossRef] [PubMed]

54. Wang, J.; Zeng, Q.; Zhu, J.; Liu, G.; Tang, H. Dissimilarity of ascorbate-glutathione (AsA-GSH) cycle mechanism in two rice (Oryza sativa L.) cultivars under experimental free-air ozone exposure. Agric. Ecosyst. Environ. 2013, 165, 39-49. [CrossRef]

55. Singh, A.A.; Agrawal, S.B.; Shahi, J.P.; Agrawal, S.B. Assessment of growth and yield losses in two Zea mays L. cultivars (quality protein maize and nonquality protein maize) under projected levels of ozone. Environ. Sci. Pollut. Res. 2013, 21, 2628-2641. [CrossRef] [PubMed]

56. Ong, M.K.; Kazi, F.K.; Forney, C.F.; Ali, A. Effect of Gaseous Ozone on Papaya Anthracnose. Food Bioprocess Technol. 2012, 6, 2996-3005. [CrossRef]

57. Rai, R.; Agrawal, S.B.; Agrawal, S.B. Assessment of yield losses in tropical wheat using open top chambers. Atmos. Environ. 2007, 41, 9543-9554. [CrossRef]

Publisher's Note: MDPI stays neutral with regard to jurisdictional claims in published maps and institutional affiliations.

(C) 2020 by the authors. Licensee MDPI, Basel, Switzerland. This article is an open access article distributed under the terms and conditions of the Creative Commons Attribution (CC BY) license (http://creativecommons.org/licenses/by/4.0/). 